\title{
GROWTH OF MARANDU PALISADEGRASS SUBJECTED TO STRATEGIES OF INTERMITTENT STOCKING
}

\author{
Alessandra Aparecida Giacomini ${ }^{1}$; Sila Carneiro da Silva ${ }^{2 *}$; Daniel Oliveira de Lucena \\ Sarmento ${ }^{1}$; Cauê Varesqui Zeferino ${ }^{1}$; Salim Jacaúna Souza Júnior ${ }^{1}$; Júlio Kuhn da Trindade ${ }^{1}$; \\ Vítor del'Alamo Guarda'; Domicio do Nascimento Júnior ${ }^{3}$ \\ ${ }^{1}$ USP/ESALQ - Programa de Pós-Graduação em Ciência Animal e Pastagens. \\ ${ }^{2}$ USP/ESALQ - Depto. de Zootecnia, C.P. 09 -13418-900 - Piracicaba, SP - Brasil. \\ ${ }^{3} U F V$ - Depto. de Zootecnia, - 36571-000 - Viçosa, MG - Brasil. \\ *Corresponding author <scdsilva@esalq.usp.br>
}

\begin{abstract}
Grazing strategies alter sward leaf area patterns of growth, affecting herbage accumulation and utilisation. The objective of this experiment was to evaluate the growth of marandu palisadegrass (Brachiaria brizantha cv. Marandu) swards subjected to strategies of intermittent stocking. The experiment was carried out in Piracicaba, São Paulo, Brazil, from October/2004 to September/2005. Swards were grazed at 95 and $100 \%$ canopy light interception (LI) to post-grazing heights of 10 and 15 $\mathrm{cm}$, following a $2 \times 2$ factorial arrangement with four replications in a randomised complete block design. The response variables evaluated were: crop growth rate, relative growth rate, net assimilation rate, leaf area ratio and leaf weight ratio. In early and late spring, the highest crop growth rate was recorded for treatment 95/15 (11.2 and $10.1 \mathrm{~g} \mathrm{~m}^{-2}$ day $^{-1}$, respectively), along with high values of net assimilation rate (4.4 and $6.9 \mathrm{~g} \mathrm{~m}^{-2}$ day ${ }^{-1}$, respectively), leaf area ratio $\left(0.0095\right.$ and $0.0103 \mathrm{~m} \mathrm{~m}^{2} \mathrm{~g}^{-1}$, respectively) and leaf weight ratio ( 0.56 and $0.56 \mathrm{~g} \mathrm{~g}^{-1}$, respectively). To compensate reductions in net assimilation rate plants made some morphological and physiological adjustments increasing leaf area and leaf weight ratio. Relative growth rate and net assimilation rate were 26 and $50 \%$ higher, respectively, on swards grazed at $95 \%$ than at $100 \%$ LI. In early spring treatments $100 / 10$ and $95 / 15$ resulted in the highest relative growth rate ( 0.086 and $0.059 \mathrm{~g} \mathrm{~m}^{-2}$ day $^{-1}$, respectively). Treatment $95 / 15$ resulted in the most favourable pattern of growth (crop growth rate, relative growth rate, net assimilation rate), particularly during the transition period between winter and spring.
\end{abstract}

Key words: Brachiaria brizantha, canopy light interception, regrowth, grazing management

\section{CRESCIMENTO DO CAPIM-MARANDU SUBMETIDO À ESTRATÉGIAS DE LOTAÇÃO INTERMITENTE}

RESUMO: Estratégias de pastejo alteram a área foliar dos pastos, interferindo em seus padrões de crescimento e afetando o acúmulo e a utilização de forragem. O objetivo desse experimento foi avaliar o crescimento de pastos de capim-marandu (Brachiaria brizantha cv. Marandu) submetidos a estratégias de lotação intermitente. O experimento foi realizado em Piracicaba, SP, Brasil, de Outubro/ 2004 a Setembro/2005. Os pastejos foram realizados quando o dossel atingia 95 ou $100 \%$ de interceptação luminosa (IL) até as alturas pós-pastejo de 10 e $15 \mathrm{~cm}$, seguindo um arranjo fatorial $2 \times 2 \mathrm{com} 4$ repetições e um delineamento de blocos completos casualizados. Avaliaram-se a taxa de crescimento da cultura, a taxa de crescimento relativo, a taxa de assimilação líquida, a razão de área foliar e a razão de peso foliar. No início e final de primavera a maior taxa de crescimento da cultura foi registrada para o tratamento $95 / 15$ (11.2 e $10.1 \mathrm{~g} \mathrm{~m}^{-2} \mathrm{dia}^{-1}$, respectivamente), associada a altos valores de taxa de assimilação líquida (4.4 e $6.9 \mathrm{~g} \mathrm{~m}^{-2} \mathrm{dia}^{-1}$, respectivamente), razão de área foliar $\left(0.0095 \mathrm{e} 0.0103 \mathrm{~m}^{2} \mathrm{~g}^{-1}\right.$, respectivamente) e razão de peso foliar $\left(0.56\right.$ e $0.56 \mathrm{~g} \mathrm{~g}^{-1}$, respectivamente). Para compensar reduções em taxa de assimilação líquida a planta se ajustou morfológica e fisiologicamente aumentando a razão de área foliar e razão de peso foliar. A taxa de crescimento relativo e a taxa de assimilação líquida foram, respectivamente, $26 \%$ e $50 \%$ superiores nos pastos manejados com $95 \%$ relativamente àqueles com $100 \%$ de IL. No início de primavera os tratamentos 100/10 e 95/15 resultaram na maior taxa de crescimento relativo $\left(0.086\right.$ e $0.059 \mathrm{~g} \mathrm{~m}^{-2} \mathrm{dia}^{-1}$, respectivamente). $\mathrm{O}$ tratamento $95 / 15$ resultou no padrão mais favorável de crescimento (taxas de crescimento da cultura, crescimento relativo e assimilatória líquida), particularmente durante o período de transição entre inverno e primavera.

Palavras-chave: Brachiaria brizantha, interceptação luminosa, manejo do pastejo, rebrotação

Sci. Agric. (Piracicaba, Braz.), v.66, n.6, p.733-741, November/December 2009 


\section{INTRODUCTION}

In pastoral systems of animal production, efficient harvest of herbage is one of the main features determining system's productivity. However, it interferes with regrowth after grazing by altering patterns of growth and influencing the accumulation of morphological components, affecting nutritive value and dry matter intake (Da Silva, 2004). These modifications are caused by morphophysiological adaptations of forage plants to management practices and environmental conditions (Beadle, 1993). Knowledge on how these adaptations take place and how they relate to management practices like grazing frequency and severity would certainly allow planning of efficient grazing management strategies, favouring animal production and productivity.

Radford (1967) described a growth analysis method used to study the growth curve of forage plants during regrowth. The analysis uses variables that allow inferences to be made on some physiological aspects of plant development like photosynthesis, respiration and carbon allocation (McGraw \& Garbutt, 1990) from agronomic data. These same variables could be used to assess the impact of grazing management strategies on plant responses under field conditions and contribute to the understanding of the general agronomic performance of plants in standard grazing experiments. The study of these variables is interesting because, while herbage accumulation represents only the balance between growth and senescence (Hodgson, 1990) and morphological composition the partitioning of photo-assimilates, growth analysis involves the effects of several other processes like photosynthesis, respiration, carbon allocation etc. (McGraw \& Garbutt, 1990).

Assuming that management practices and seasonal climatic variations affect plant growth and the processes of photosynthesis, respiration and carbon allocation in forage plants, the objective of this experiment was to evaluate the growth patterns of marandu palisadegrass swards (Brachiaria brizantha cv. Marandu) subjected to strategies of intermittent stocking using the basic assumptions of a traditional growth analysis. The present experiment was part of a series of experiments designed to evaluate plant and animal responses to strategies of intermittent stocking and carried out concomitantly in the same experimental area: sward structure, foliage angle, light interception and herbage accumulation (Souza Jr., 2007); morphogenetic responses and dynamics of herbage accumulation (Zeferino, 2006); tiller demography, tillering dynamics and patterns of growth (Giacomini, 2007); herbage morphological composition and nutritive value
(Sarmento, 2007); modifications in sward structure and ingestive behaviour of cattle during the grazing down process (Trindade, 2007). The objective was to evaluate the effect of pre-grazing sward light interception (LI) and post-grazing height targets on leaf area formation (including the separate contribution of basal and aerial tillers) of intermittently stocked marandu palisadegrass swards.

\section{MATERIAL AND METHODS}

The experiment was conducted in Piracicaba, São Paulo, Brazil (22 $42^{\prime}$ ' S, $47^{\circ} 37^{\prime} \mathrm{W}$ and $550 \mathrm{~m}$ a.s.1.), on a Brachiaria brizantha cv. Marandu pasture (marandu palisadegrass) established in 2001 on an Eutric Kandiudalf. Average soil chemical characteristics (Raij et al., 1986) for the 0-20 cm layer were: $\mathrm{pH}$ $\mathrm{CaCl}_{2}: 5.6 ; \mathrm{OM}=41 \mathrm{dg} \mathrm{dm}^{-3} ; \mathrm{P}$ (ion-exchange resin extraction method) $=67 \mathrm{mg} \mathrm{dm}^{-3} ; \mathrm{Ca}=74 \mathrm{mmol}_{\mathrm{c}} \mathrm{dm}^{-3}$; $\mathrm{Mg}=19 \mathrm{mmol}_{\mathrm{c}} \mathrm{dm}^{-3} ; \mathrm{K}=6.5 \mathrm{mmol}_{\mathrm{c}} \mathrm{dm}^{-3} ; \mathrm{H}+\mathrm{Al}=$ $36 \mathrm{mmol}_{\mathrm{c}} \mathrm{dm}^{-3}$; sum of bases $=99 \mathrm{mmol}_{\mathrm{c}}^{\mathrm{c}} \mathrm{dm}^{-3}$; cation exchange capacity $=134.8 \mathrm{mmol}_{\mathrm{c}} \mathrm{dm}^{-3}$; base saturation $=74 \%$.

Marandu palisadegrass swards were grazed under continuous stocking from October 2001 until February 2003 and then under intermittent stocking until February 2004 , when they were staged to approximately $8 \mathrm{~cm}$ in preparation for the experiment. Treatments followed the factorial arrangement of two pre-grazing light interseption LI (95 or 100\%) and two post-grazing heights $(10$ or $15 \mathrm{~cm})$. Experimental units were $1,200 \mathrm{~m}^{2}$ paddocks organised in a randomised complete block design, with four replications. Treatments were firstly assigned to experimental units in March 2004, and measurements started in October 2004 and were performed until September 2005. Paddocks were grazed by 2 year old Nelore (Bos indicus) and Canchim (Bos sp.) heifers with an average body weight of 350 $\mathrm{kg}$ and 4 to 6 year old cows with an average body weight of $540 \mathrm{~kg}$ using the mob grazing method described by Gildersleeve et al. (1987). The number of animals used during each grazing was dimensioned in order to allow for a grazing period no longer than 12 $\mathrm{h}$ (grazing during day time only).

Paddocks were fertilised with $\mathrm{N}, \mathrm{K}$ and $\mathrm{S}$ using a commercial formula 30-00-20 (N-P $\left.\mathrm{O}_{5}-\mathrm{K}_{2} \mathrm{O}\right)$ applied in instalments after grazings, totalling $110 \mathrm{~kg} \mathrm{ha}^{-1}$ of $\mathrm{N}$, $22 \mathrm{~kg} \mathrm{ha}^{-1}$ of $\mathrm{S}$, and $60 \mathrm{~kg} \mathrm{ha}^{-1}$ of $\mathrm{K}$. The amounts of $\mathrm{N}$ applied and their times of application throughout the experimental period were: $30 \mathrm{~kg} \mathrm{ha}^{-1}$ between November and December/2004; $30 \mathrm{~kg} \mathrm{ha}^{-1}$ between January and February/2005; $50 \mathrm{~kg} \mathrm{ha}^{-1}$ in April/2005.

Mean air temperature indicated that autumn, winter and early spring were relatively warmer, and sum- 
mer was drier and autumn was wetter than the 90year average (Figure 1). There was soil water deficit (Thornthwaite \& Mather, 1955) during late summer/ early autumn and winter/early spring (Figure 2).

Monitoring of canopy LI was performed using a canopy analyser LAI 2000 (LI-COR, Lincoln, Nebraska, USA) and readings were taken at post-grazing, after 5 $\mathrm{cm}$ increase in sward height from post-grazing height, and every two days after a reading of $90 \%$ until the pregrazing targets of 95 and $100 \%$ LI were reached. Measurements were conducted in ten sampling areas per experimental unit (representative of the average sward condition at the time of sampling - visual assessment of height and herbage mass). In each paddock, five readings were taken at ground level and one above canopy from each sampling area. Measurements of sward height were made at the same time measurements of LI were made using a ruler and an acetate sheet (Fagundes et al., 1999). A total of 20 readings were consistently taken along pre-defined trajectories in each paddock throughout the experimental period.

Measurements on individual tillers were made on 60 tillers harvested from each paddock on sites where sward height corresponded to the average condition for the paddock at the time of sampling. Samples were collected in six locations per paddock with ten tillers being collected per point (including all daughter tillers attached). These were cut with scissors close to the

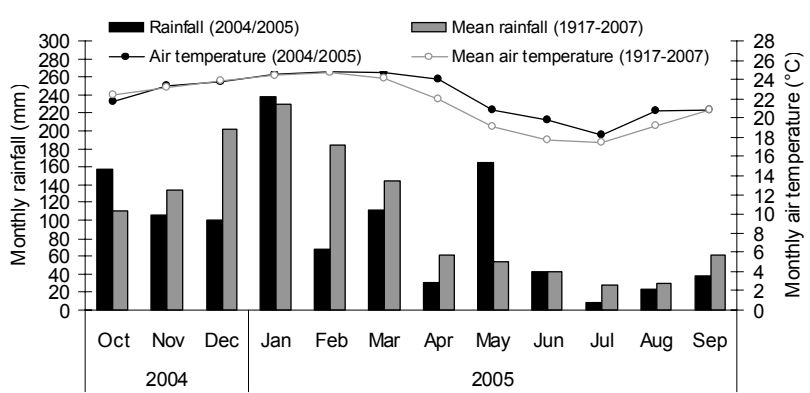

Figure 1 - Monthly and historical means of rainfall and air temperature from October 2004 to September 2005.

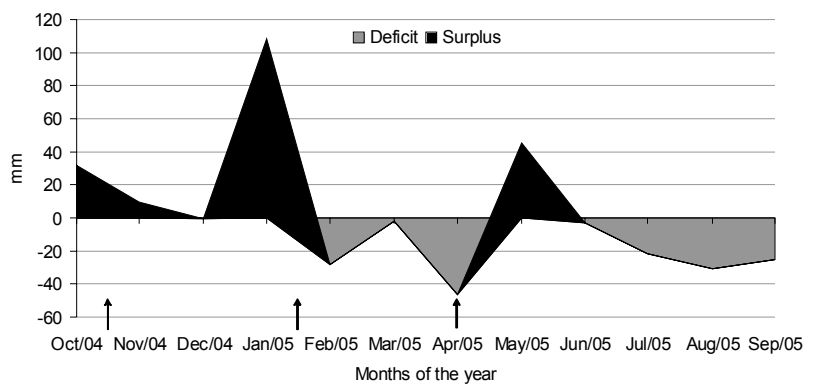

Figure 2 - Monthly soil water balance (calculated considering a soil water storage capacity of $50 \mathrm{~mm}$ ) from October 2004 to September 2005 (Arrows indicate time when nitrogen was applied on swards). ground, identified, placed into plastic bags and taken immediately to the laboratory for measurements. Harvests were performed at pre and post-grazing and every $5 \mathrm{~cm}$ increase in sward height from post-grazing height during re-growth. In this last case, after the experiment end, because of the varying number of increments in sward height between treatments, data were used to calculate a value that would correspond to the mid point of each grazing interval (intermediary phase - condition where sward height was equal to the arithmetic mean between pre and post-grazing heights), from October 2004 to September 2005.

Sixty tillers were randomly selected from tiller samples for further evaluation. After tillers had been separated into basal and aerial, the morphological components of the tillers (leaf (leaf laminae), stem (stem + leaf sheath) and dead material) were hand dissected, weighed separately to determine their fresh weight, and leaf lamina measured using a leaf area integrator LI 3100 (LI-COR, Lincoln, Nebraska, USA) for determining the mean leaf area per tiller. Components were placed into paper bags, dried in forced draught oven at $65^{\circ} \mathrm{C}$ for 48 hours and weighed. The fresh and dry weight of leaves for individual tillers in each category (basal and aerial) were presented as arithmetic means. Sward leaf area index (LAI) was calculated using the equation $\mathrm{LAI}=\mathrm{TPD} \times \mathrm{LAT}$, where TPD is tiller population density (tillers $\mathrm{m}^{-2}$ ) (Giacomini, 2007) and LAT the mean leaf area per tiller $\left(\mathrm{m}^{2}\right)$.

Mean leaf and stem dry weight of individual tillers were multiplied by tiller population density (tillers $\mathrm{m}^{-2}$; Giacomini, 2007), generating the total herbage dry weight per square meter. The variables crop growth rate (CGR; $\mathrm{g} \mathrm{m}^{-2}$ day $^{-1}$ ), relative growth rate (RGR; $g$ $\mathrm{g}^{-1}$ day $^{-1}$ ), net assimilation rate (NAR; $\mathrm{g} \mathrm{m}^{-2}$ day $^{-1}$ ) and leaf area ratio (LAR; $\mathrm{m}^{-2} \mathrm{~g}^{-1}$ ) were calculated using the values of total herbage dry weight per unit area and LAI according to Radford (1967), and leaf weight ratio (LWR; $\mathrm{g} \mathrm{g}^{-1}$ ) according to Benincasa (1988). Before performing the calculations, the total herbage dry weight per unit area and LAI data were plotted against days of growth during each regrowth period and a positive, linear relationship detected, indicating that the basic assumptions of the traditional growth analysis as described by Radford (1967) were being respected. The equations used for calculating the growth analysis variables (CGR, RGR, NAR, LAR and LWR) were:

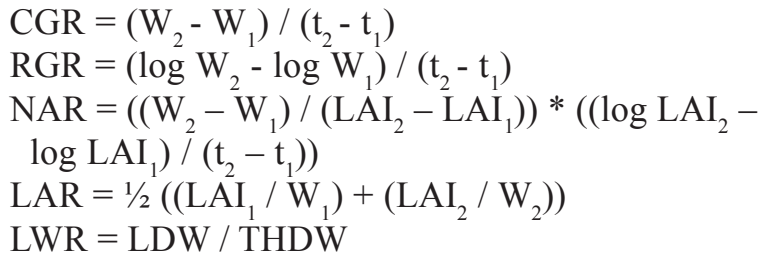


where: $\mathrm{W}_{1}$ and $\mathrm{W}_{2}$ correspond to the total herbage dry weight (THDW) at times $t_{1}$ (post-grazing) and $t_{2}$ (pregrazing), respectively; $\mathrm{LAI}_{1}$ and $\mathrm{LAI}_{2}$ are the leaf area indexes at times $t_{1}$ and $t_{2}$, respectively; LDW is leaf dry weight; and THDW is the total herbage dry weight per unit area.

Because pre-grazing conditions were defined in terms of sward canopy light interception levels, grazing dates and rest periods for each paddock were variable and dependent on the prevailing environmental growth conditions. To establish a common basis for analysis, data were grouped into seasons of the year within which general behaviour was similar but represented changes in patterns of plant responses throughout the experimental period: early spring 2004 (October and November 2004); late spring 2004 (December 2004); summer 2005 (January to March 2005); and autumn/winter 2005 (April to September 2005. Values for individual paddocks were weighted for the number of records within seasons. Data were analysed as repeated measures using the Mixed Procedure (Littel et al., 1998) of SAS ${ }^{\circledR}$ (Statistical Analysis System). The choice of the covariance matrix was made using the Akaike Information Criterion (AIC) (Wolfinger, 1993). Pre-grazing light interception, post-grazing height and season of the year were considered fixed effects and blocks and its interactions considered random effects. When appropriate, the means reported are least square means ("LSMEANS"), and the comparisons made with "PDIFF" based on a Student $t$ test and a 10\% significance level.

\section{RESULTS}

Nominal values for the $95 \%$ LI treatments remained close to target throughout the experimental period (Table 1). However, for the $100 \%$ LI treatments, values varied between 97.4 to $98.2 \%$ depending on season of the year.

Crop growth rate (CGR) varied with LI ( $p=$ $0.0301)$, season of the year $(p=0.0011)$ and the postgrazing height $\times$ season of the year $(p=0.0383)$ and post-grazing height $\times \mathrm{LI} \times$ season of the year interactions $(p=0.0841)$. Swards managed at $95 \%$ LI showed higher crop growth rate (CGR) than those managed at $100 \%$ LI $\left(7.08\right.$ and $5.23 \mathrm{~g} \mathrm{~m}^{-2}$ day $\left.^{-1}\right)$. The lowest values of CGR were recorded in autumn/winter 2005. In early and late spring 2004 treatment 95/ 15 resulted in the highest value of CGR. In summer 2005 the highest CGR was recorded on swards subjected to the 95/10 treatment (Figure 3).

Relative growth rate (RGR) was affected by post-grazing height ( $p=0.0193$ ), season of the year $(p<0.0001)$ and post-grazing height $\times \mathrm{LI} \times$ season of the year interaction $(p=0.0712)$. Higher RGR values were recorded on swards grazed to $10 \mathrm{~cm}$ relative to those grazed to $15 \mathrm{~cm}\left(0.061\right.$ and $0.036 \mathrm{~g} \mathrm{~g}^{-1}$ day $^{-1}$, respectively). The highest value of RGR (0.097 $\mathrm{g} \mathrm{g}^{-1}$ day $^{-1}$ ) was recorded in late spring 2004 and the lowest $\left(0.013 \mathrm{~g} \mathrm{~g}^{-1}\right.$ day $\left.^{-1}\right)$ in autumn/winter $2005(p<$ 0.0001 ). Swards managed with treatment $95 / 10$ had higher RGR in late spring 2004 and summer 2005. In early spring 2004 treatments 100/10 and 95/15 resulted in the highest values of RGR (Figure 4).

Net assimilation rate (NAR) varied with LI ( $p=$ $0.0183)$, season of the year $(p=0.0027)$ and postgrazing height $\times$ season of the year $(p=0.0978)$ and post-grazing height $\times$ LI $\times$ season of the year $(p=$ $0.0435)$ interactions. Recorded values of NAR were higher on swards managed at $95 \%$ than at $100 \% \mathrm{LI}$ (4.58 and $2.27 \mathrm{~g} \mathrm{~m}^{-2}$ day $^{-1}$ ). NAR did not vary throughout the year, except in autumn/winter 2005 when the lowest value was recorded $(4.16,3.93,5.10$

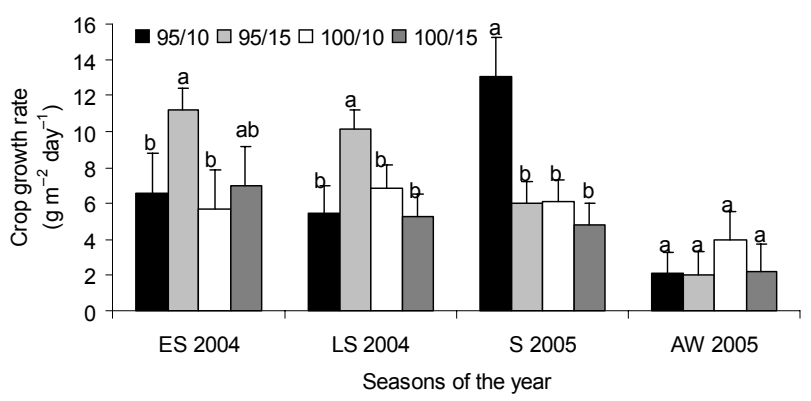

$\mathrm{ES}=$ early spring (October and November); LS = late spring (December); $\mathrm{S}=$ Summer (January to March) and AW = autumn/ winter (April to September). Lower case letters compare treatment means within seasons of the year. Vertical bars correspond to standard error of the mean.

Figure 3 - Crop growth rate of marandu palisadegrass swards subjected to strategies of intermittent stocking from October 2004 to September 2005.

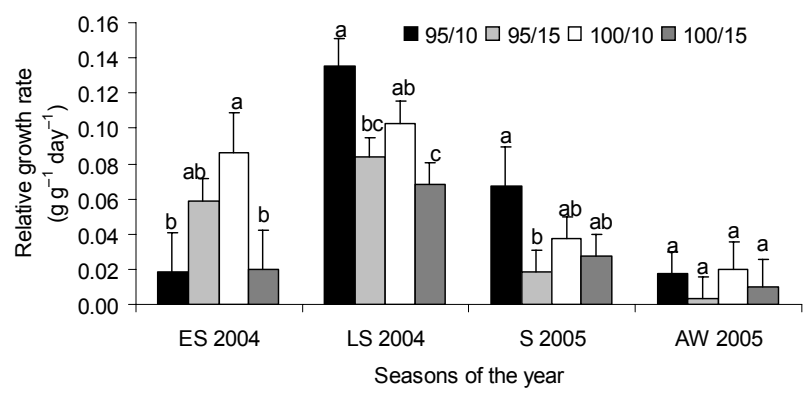

$\mathrm{ES}=$ early spring (October and November); LS = late spring (December); $\mathrm{S}=$ Summer (January to March) and AW = autumn/ winter (April to September). Lower case letters compare treatment means within seasons of the year; Vertical bars correspond to standard error of the mean

Figure 4 - Relative growth rate of marandu palisadegrass swards subjected to strategies of intermittent stocking from October 2004 to September 2005. 
Table 1 - Canopy light interception and sward height pre-grazing and grazing intervals of marandu palisadegrass subjected to strategies of intermittent stocking from October 2004 to December $2005^{*}$.

\begin{tabular}{|c|c|c|c|c|c|c|c|c|c|c|}
\hline \multirow{2}{*}{ Seasons } & \multicolumn{2}{|c|}{ LI $(\%)$} & \multicolumn{4}{|c|}{ Sward height pre-grazing $(\mathrm{cm})$} & \multicolumn{4}{|c|}{ Grazing interval (days) } \\
\hline & 95 & 100 & $95 / 10$ & $95 / 15$ & $100 / 10$ & $100 / 15$ & $95 / 10$ & $95 / 15$ & $100 / 10$ & $100 / 15$ \\
\hline SP 04 & $\begin{array}{c}94.7 \\
(0.22)\end{array}$ & $\begin{array}{c}98.2 \\
(0.18)\end{array}$ & $\begin{array}{c}30.4 \\
(1.89)\end{array}$ & $\begin{array}{c}28.2 \\
(1.89)\end{array}$ & $\begin{array}{c}39.8 \\
(1.89)\end{array}$ & $\begin{array}{c}42.6 \\
(1.89)\end{array}$ & 48 & 24 & 42 & 56 \\
\hline S 05 & $\begin{array}{c}94.9 \\
(0.12)\end{array}$ & $\begin{array}{c}98.1 \\
(0.13)\end{array}$ & $\begin{array}{c}26.0 \\
(1.44)\end{array}$ & $\begin{array}{c}21.5 \\
(1.44)\end{array}$ & $\begin{array}{c}37.8 \\
(1.44)\end{array}$ & $\begin{array}{c}33.9 \\
(1.44)\end{array}$ & 60 & 30 & 59 & 61 \\
\hline AW 05 & $\begin{array}{c}95.0 \\
(0.09)\end{array}$ & $\begin{array}{c}97.4 \\
(0.08)\end{array}$ & $\begin{array}{c}23.8 \\
(0.92)\end{array}$ & $\begin{array}{c}20.5 \\
(0.64)\end{array}$ & $\begin{array}{c}29.4 \\
(0.74)\end{array}$ & $\begin{array}{c}32.3 \\
(0.74)\end{array}$ & 234 & 215 & 210 & 214 \\
\hline
\end{tabular}

$\mathrm{SP}=$ spring (October to December); $\mathrm{S}=$ summer (January to March) and AW = autumn/winter (April to September). Numbers in parentheses correspond to standard error of the mean. *Adapted from Souza Jr., 2007

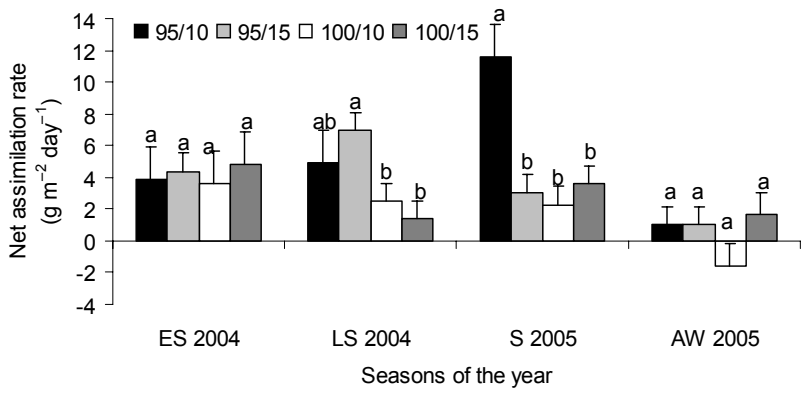

$\mathrm{ES}=$ early spring (October and November); LS = late spring (December); $\mathrm{S}=$ Summer (January to March) and AW = autumn/ winter (April to September). Lower case letters compare treatment means within seasons of the year; Vertical bars correspond to standard error of the mean

Figure 5 - Net assimilation rate of marandu palisadegrass swards subjected to strategies of intermittent stocking from October 2004 to September 2005.

and $0.51 \mathrm{~g} \mathrm{~m}^{-2}$ day $^{-1}$ in early and late spring 2004 , summer and autumn/winter 2005, respectively). The highest value of NAR in late spring 2004 was recorded for treatment 95/15 and, in summer 2005, for treatment 95/10 (Figure 5).

Leaf area ratio (LAR) was affected by post-grazing height $(p=0.0198)$, season of the year $(p<$ $0.0001)$ and post-grazing height $\times$ season of the year $(p=0.0564)$ and post-grazing height $\times$ LI $\times$ season of the year $(p=0.0016)$ interactions. Swards grazed at $10 \mathrm{~cm}$ residue presented lower LAR than those grazed at $15 \mathrm{~cm}\left(0.009\right.$ and $\left.0.011 \mathrm{~m}^{2} \mathrm{~g}^{-1}\right)$. The lowest value of LAR was recorded in early spring 2004 $\left(0.007 \mathrm{~m}^{2} \mathrm{~g}^{-1}\right)$, but it increased in late spring 2004 $\left(0.009 \mathrm{~m}^{2} \mathrm{~g}^{-1}\right)$ and in summer $2005\left(0.012 \mathrm{~m}^{2} \mathrm{~g}^{-1}\right)$, and decreased in autumn/winter $2005\left(0.010 \mathrm{~m}^{2} \mathrm{~g}^{-1}\right)$. Treatment 95/15 resulted in high values of LAR relative to other treatments throughout the experimental period and, in early spring 2004 , treatment $100 / 10$ also showed high values of LAR (Figure 6).

Leaf weight ratio (LWR) varied with post-grazing height $(p=0.0005)$, LI $(p=0.0735)$, season of the year $(p<0.0001)$ and LI $\times$ season of the year $(p=$ $0.0046)$ interaction. Values of LWR were higher on

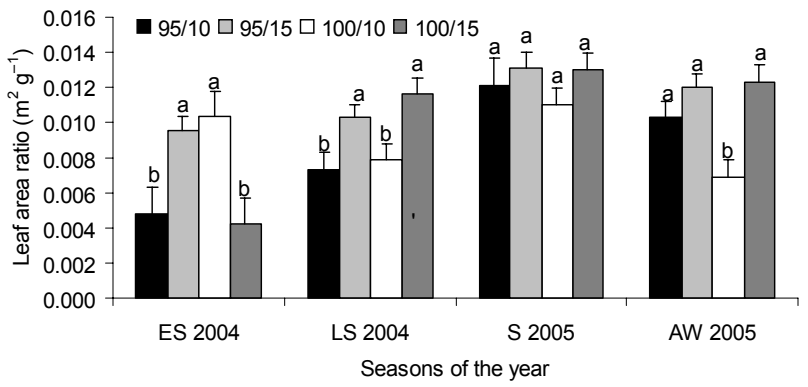

$\mathrm{ES}=$ early spring (October and November); LS = late spring (December); $\mathrm{S}=$ Summer (January to March) and AW = autumn/ winter (April to September). Lower case letters compare treatment means within seasons of the year; Vertical bars correspond to standard error of the mean.

Figure 6 - Leaf area ratio of marandu palisadegrass swards subjected to strategies of intermittent stocking from October 2004 to September 2005.

swards grazed at $10 \mathrm{~cm}$ residue than those grazed at $15 \mathrm{~cm}$ ( 0.579 and $0.543 \mathrm{~g} \mathrm{~g}^{-1}$, respectively). The highest values of LWR were recorded in summer and autumn/winter 2005 ( 0.583 and $0.574 \mathrm{~g} \mathrm{~g}^{-1}$, respectively) relative to early and late spring 2004 ( 0.550 and 0.537 $\mathrm{g} \mathrm{g}^{-1}$, respectively). Only in late spring 2004 the $95 \%$ LI treatments resulted in higher LWR than the $100 \%$ LI treatments. The highest LWR of swards managed at $95 \% \mathrm{LI}$ was recorded in summer 2005 and the lowest in early spring 2004 . For the $100 \%$ LI treatments, the highest values were recorded in summer and autumn/winter 2005 and the lowest in late spring 2004 (Figure 7).

\section{DISCUSSION}

Crop growth rate (CGR) corresponds to the variation in herbage mass between two successive samplings and, for that reason, can be used as an indicative how fast plants grow during an observation period (Benincasa, 1988). In this experiment, treatment 95/15 resulted in the highest CGR in early and late spring 2005 (Figure 3), a likely consequence of the highest proportion of leaf in post-grazing herbage mass 




$\mathrm{ES}=$ early spring (October and November); LS = late spring (December); $\mathrm{S}=$ Summer (January to March) and AW = autumn/ winter (April to September). Upper case letters compare treatment means within seasons of the year; Lower case letters compare seasons of the year means within levels of LI; Vertical bars correspond to standard error of the mean.

Figure 7 - Leaf weight ratio of marandu palisadegrass swards subjected to strategies of intermittent stocking from October 2004 to September 2005.

(Sarmento, 2007). Net accumulation rate (NAR) and sward leaf area index (LAI) are considered CGR components (Benincasa, 1988). Since in early and late spring 2004 the highest values of NAR were recorded for treatment 95/15 (Figure 5), which had the lowest LAI in early spring (Figure $8 ; p=0.0479$ ) and similar LAI to treatment $100 / 10$ in late spring 2004 , it can be inferred that CGR was mainly determined by NAR in relation to LAI. From late spring 2004 to summer 2005 there was a $41 \%$ reduction in CGR for treatment $95 /$ 15 , which could have been caused by the 56 and $29 \%$ reduction in NAR and LAI, respectively. The highest proportion of dead material (Sarmento, 2007) and the largest number of grazings (Souza Jr., 2007) in early and late spring 2004 on swards managed with treatment 95/15 may have contributed to the reduction in CGR.

In summer 2005 the highest value of NAR seemed to be the major determinant of the highest value of CGR for treatment $95 / 10$, suggesting that NAR was relatively more important than LAI in determining CGR, since LAI values for treatment 95/10 were intermediate between the $100 \%$ LI treatments $(100 / 10$ and 100/15) and treatment 95/15. This same relationship between NAR and LAI for determining CGR was detected for treatments $100 / 10$ and $100 / 15$, since they had the highest values of LAI (Figure 8), but the lowest values of CGR and NAR when compared to the other treatments. This indicates that the size of the photosynthetic apparatus was not as effective as the photosynthetic efficiency of sward canopy in determining growth rate, suggesting that management practices that favour the production of new, photosynthetically efficient tissue, as an adequate frequency of graz-

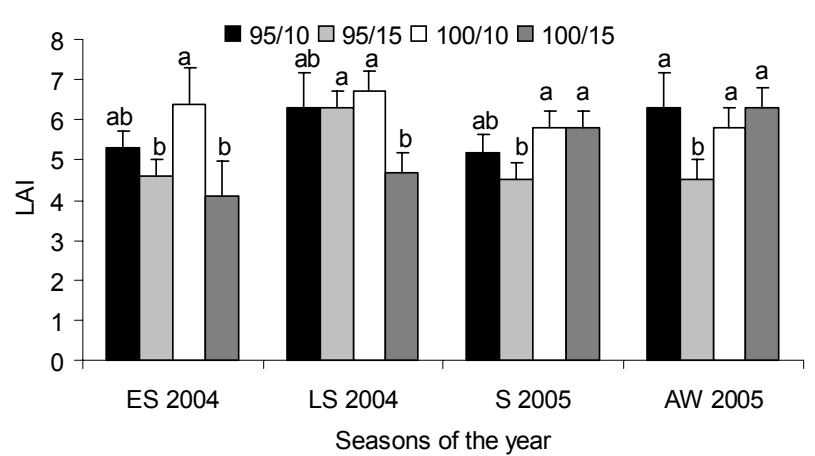

$\mathrm{ES}=$ early spring (October and November); LS = late spring (December); $\mathrm{S}=$ Summer (January to March) and AW = autumn/ winter (April to September). Lower case letters compare treatment means within seasons of the year; Vertical bars correspond to standard error of the mean.

Figure 8 - Leaf area index of marandu palisadegrass swards subjected to strategies of intermittent stocking from October 2004 to September 2005

ing, may optimise the use of the incident light by forage plants.

Treatment 95/10 resulted in the lowest proportion of dead material in the pre-grazing herbage mass in early and late spring 2004 and summer 2005 (Sarmento, 2007). This low proportion of dead material would theoretically allow a larger proportion of the incident light to be intercepted by green leaves, favouring the occurrence of high NAR and CGR. However, since this treatment resulted in a longer grazing interval than treatment 95/15 (Table 1), as a consequence of the lower post-grazing height, CGR was lower in early and late spring 2004 and high values of CGR and NAR recorded only in summer 2005. During summer, treatment $95 / 10$ had the highest proportion of leaf and lowest proportion of stem in the herbage mass pre-grazing (Sarmento, 2007). This larger proportion of green leaves suggests greater photosynthetic activity and, consequently, higher NAR, which contributed to increase CGR, a pattern of response that corroborates the findings of Ferreira (2001) also for marandu palisadegrass.

The results of this experiment corroborates the findings of Watson (1958) that at 95\% LI, when most of the incident light is being intercepted with a minimum of self-shading within the sward, CGR is highest, consequence of an optimum balance between photosynthesis and respiration, i.e. NAR (Lambers, 1987). Swards managed at $100 \%$ LI presented low CGR, probably caused by the decrease in photosynthesis/respiration ratio due to excessive shading that may have resulted in a negative carbon balance (Hay \& Walker, 1989) and low NAR (Figure 5), particularly during periods of high air temperature and rainfall (late spring 2004 and summer 2005). The low NAR on swards 
managed at $100 \%$ LI may be attributed to the reduction of the sward net photosynthetic activity caused by the aging process of leaves, self-shading between them and increase in respiratory costs, all factors that compromise sward net photosynthesis (Woledge, 1977). Further, a higher accumulation of stem and dead material (Sarmento, 2007) and senescence (Zeferino, 2006) were also recorded for the $100 \%$ relative to the $95 \%$ LI treatments, a condition likely associated to higher respiration losses that contributed to lower values of NAR in late spring 2004 and summer 2005.

Relative growth rate (RGR) consists of an increase in plant mass, and its components are NAR and leaf area ratio (LAR). It considers all plant biomass above ground level as equally productive, but it is known that leaves are the structures that most contribute to plant growth and dry matter accumulation. In early spring 2004, the highest RGR was recorded for treatment 100/10 (Figure 4), a likely consequence of its high LAR (Figure 6). A similar pattern of response was also detected for treatment $95 / 15$, which had a high RGR and LAR, indicating that RGR was more influenced by LAR than NAR at that time of the year. This corroborates the statement of Poorter (1989) that LAR is the main determinant of RGR, and is accordance with the findings of Santos Jr. et al. (2004) and Oliveira et al. (2000) for marandu palisadegrass and Tifton 85 bermudagrass (Cynodon sp. cultivar), respectively. Based on the high values of CGR and RGR recorded in early spring 2004, it might be inferred that re-establishment of fast sward growth during spring is strongly influenced by grazing management, and could be optimised on swards subjected to treatment 95/15.

In late spring 2004 RGR for all treatments were higher than those in early spring, and highest values recorded in summer 2005 (Figure 4). Treatments 95/ 10 and 100/10 showed the highest RGR, resulting in a $41 \%$ higher RGR for the $10 \mathrm{~cm}$ relative to the 15 $\mathrm{cm}$ post-grazing height treatments. Since RGR corresponds to an efficiency index representing plant's ability to produce new tissue, the $10 \mathrm{~cm}$ post-grazing height treatments generated more efficient growth conditions. Additionally, it was on swards grazed down to $10 \mathrm{~cm}$ that the proportion of dead material in the pre-grazing herbage mass was lowest (Sarmento, 2007), allowing for a larger quantity and better quality of light into the canopy and favouring the appearance of aerial tillers (Giacomini, 2007) by the activation of axillary buds. Under those conditions, sward growth received a significant contribution of newly formed aerial tillers, more efficient photosynthetically, which probably contributed to the increase in RGR without the need to a corresponding increase in LAR in late spring 2004.
LAR increased for all treatments from early to late spring 2004 (Figure 6). However, in late spring, higher LAR was recorded for treatments $95 / 15$ and $100 / 15$, which did not contribute to high RGR for those treatments. Instead, high values of RGR were recorded for treatments 95/10 and 100/10. On the other hand, LAR and NAR were lower on swards grazed down to 10 $\mathrm{cm}$ than on those grazed down to $15 \mathrm{~cm}$, suggesting that the higher values of RGR must have been consequence of the intense aerial tillering under the more severe grazing at that time of the year (Giacomini, 2007), explaining the higher RGR of swards subjected to treatments 95/10 and 100/10. The result of this intense aerial tillering process was perceived in the next season, summer 2005, when the highest values of LAR and NAR were recorded for treatment 95/10.

From late spring 2004 to summer 2005 there was a $21 \%$ increase in LAR for treatment $95 / 15$, probably to compensate its low NAR, which was not enough to increase CGR and RGR. Since LAR has as components the specific leaf area (SLA) and the leaf weight ratio (LWR) (Benincasa, 1988), it can be assumed that the increase in LAR was consequence of the increase in SLA (Giacomini, 2007) and LWR (Figure 7). This is an indicative that there must have been a larger investment in thinner leaves, but with higher photosynthesis rate per unit mass, contributing to a larger proportion of the dry matter accumulated to remain on leaves and not be exported to other parts of the plant. Based on that, it can be assumed that, in an attempt to compensate the reduction in NAR, plants suffered physiological and morphological adaptations in order to increase LAR. Possibly, the lower values of CGR and NAR in summer 2005 relative to those in late spring 2004 could also be associated with the negative soil water balance in summer 2005 (Figure 2).

Similarly to what happened to the $95 \%$ LI treatments, there was an increase in LAR for the $100 \% \mathrm{LI}$ treatments from late spring 2004 to summer 2005, with similar values of LAR recorded for both 95 and 100\% LI treatments in summer 2005 (Figure 6). Since swards managed at $100 \%$ LI were taller than those managed at $95 \% \mathrm{LI}$, it is likely that competition for light was more intense under those circumstances. Low light availability within the sward requires more leaf area per unit herbage mass to compensate, which is consistent with the recorded increase in LAR. In summer 2005, the increase in SLA was 13\% greater for the $100 \%$ than the $95 \%$ LI treatments (Giacomini, 2007), the same happening with LWR (Figure 7), which contributed to the increase in LAR on swards managed at $100 \%$ LI.

The increase in LAR resulting from the increase in SLA and LWR regardless of grazing treatment suggests 
that marandu palisadegrass gives priority to the allocation of photoassimilates to leaf area formation in order to intercept the highest possible amount of light. In general, when NAR was low, LAR was high. According to Robson (1973), high LAR indicates profit in carbon economy of plants, since it reflects progressive increase in the size of the photosynthetic apparatus relative to plant dry weight, and indicates lower costs of respiration and maintenance. Therefore, there seems to be a compensatory mechanism between NAR and LAR, corroborating the findings of Poorter (1989) that there is a high negative correlation between NAR and LAR. As a result, changes in NAR can cause morphological and physiological modifications in forage plants, as demonstrated by the findings of this experiment.

Considering that leaves are the main organs responsible for dry matter accumulation (photosynthesis) and that the remaining parts of the plant depend on the exportation of assimilates from leaves, LWR represents the proportion of the accumulated dry matter that was not exported to the remaining parts of the plant. Therefore, reductions in LWR indicate a larger allocation of assimilates to the development of stems and roots (non assimilatory organs) instead of leaves. In late spring 2004 , the $100 \%$ LI treatments resulted in larger exportation of assimilates to other parts of the plants than leaves, since LWR of swards managed at $100 \%$ LI were $10 \%$ lower than those managed at 95\% LI (Figure 7) and that was the only time of the year with significant difference between treatments. In this case, the preferential destination of plant assimilates must have been the development of stems, fact that was corroborated by the highest rates of stem elongation recorded on swards managed at 100\% LI (Zeferino, 2006). Decrease in LAR must have been the result of partition of assimilates to non-photosynthetic organs like stems and roots, increasing respiratory losses and decreasing sward net photosynthesis. In the present experiment values of NAR were $50 \%$ higher on swards managed at $95 \%$ than at $100 \%$ LI. In late spring 2004 , when air temperature was higher than in early spring 2004 (Figure 1) and the water soil balance positive (Figure 2), suitable conditions for plant growth, assimilates were exported from leaves to stems as the number of days in re-growth increased and competition for light within sward canopy became more intense, especially for the $100 \%$ LI treatments. This indicates the importance of grazing interval to control the efficiency of the grazing process (Trindade, 2007).

During the remaining seasons of the year there was no LWR difference between LI treatments, indicating a constant pattern of assimilate allocation during plant growth. LWR increased from early spring 2004 to summer 2005 on swards managed at 95\% LI, suggesting that these treatments favoured the preferential allocation of assimilates to produce new leaf tissue, since leaves are the most efficient organs in carrying out photosynthesis and those of highest nutritive value and selectivity by the grazing animals. The negative effects of environmental conditions in autumn/winter such low air temperatures (Figure 1) and water soil deficit (Figure 2) were clearly reflected in the low recorded values of CGR, RGR and NAR at that time of the year regardless of the grazing treatment, indicating a strong climatic effect on plant growth.

\section{CONCLUSIONS}

Marandu palisadegrass swards subjected to intermittent stocking should be grazed at $95 \%$ LI down to a post-grazing height of $15 \mathrm{~cm}$, except during autumn/ winter, when it is assumed that there might be some benefit to reduce post-grazing height to $10 \mathrm{~cm}$.

\section{ACKNOWLEDGEMENTS}

To CNPq and FAPESP for partial funding of this research.

\section{REFERENCES}

BEADLE, D.L. Growth analysis. In: HALL, D.O.; BOLHARNORDENKAMPF, H.R.; LEEGOOD, R.C.; LONG, S.P. Photosynthesis and production in a changing environment: a field and a laboratory manual. London: Pergamon Press, 1993. p.36-46.

BENINCASA, M.M.P. Análise de crescimento de plantas: noções básicas. Jaboticabal: FUNEP, 1988. 41p.

FAGUNDES, J.L.; DA SILVA, S.C.; PEDREIRA, C.G.S; SBRISSIA, A.F.; CARNEVALLI, R.A.; CARVALHO, C.A.B.; PINTO, L.F.M. Índice de área foliar, interceptação luminosa e acúmulo de forragem em pastagens de cynodon spp. sob diferentes intensidades de pastejo. Scientia Agricola, v.56, p.1141-1150, 1999.

FERREIRA, A.M. Emergência, crescimento e senescência de uma cultivar de Brachiaria em condições de cerrado. Goiânia: Universidade Federal de Goiás, 2001. 36p. (Mestrado).

GIACOMINI, A.A. Demografia do perfilhamento e produção de forragem em pastos de capim-marandu submetidos a regimes de lotação intermitente por bovinos de corte. Piracicaba: USP/ ESALQ, 2007. 175p. (Doutorado).

GILDERSLEEVE, R.R.; OCUMPAUGH, W.R.; QUESENBERRY, K.H.; MOORE, J.E.; Mob-grazing morphologically different Aeschynomene species. Tropical Grasslands, v.21, p.123-132, 1987.

HAY, R.K.M.; WALKER, A.J. An introduction on the physiology of crop yield. Essex: Longman Scientific and Technical, 1989. 292 p.

HODGSON, J. Grazing management: science into practice. New York: John Wiley; Longman Scientific and Technical, 1990. 203p.

LAMBERS, H. Does variation in photosynthetic rate explain variation in growth rate? Netherlands Journal of Agricultural Science, v.35, p.505-519, 1987.

LITTEL, R.C.; HENRY, P.R.; AMMERMAN, C.B. Statistical analysis of repeated measures data using SAS. Journal of Animal Science, v.76, p.1216-1231, 1998. 
McGRAW, J.B.; GARBUTT, K. The analysis of plant growth in ecological and evolutionary studies. Trends in Ecology and Evolution, v.5, p.251-254, 1990.

OLIVEIRA, M.A.; PEREIRA, O.G.; GOMIDE, J.A. Análise de crescimento do capim bermuda "Tifton 85" (Cynodon spp.). Revista Brasileira de Zootecnia, v.29, p.1930-1938, 2000.

POORTER, H. Interspecific variation in relative growth rate: on ecological causes and physiological consequences. In: LAMBERS, H.; CAMBRIDGE, M.L.; KONINGS, H.; PONS, T.L. (Ed.) Causes and consequences of variation in growth rate and productivity of higher plants. The Hage: SPB Academic, 1989. p.45-68.

RADFORD, P.J. Growth analysis formulae: their use and abuse. Crop Science, v.7, p.171-175, 1967.

RAIJ, B. van.; QUAGGIO, J.A.; SILVA, N.M. Extraction of phosphorus, potassium, calcium, and magnesium from soils by ion-exchange resin procedure. Communications in Soil Science and Plant Analysis, v.17, p.547-566, 1986.

ROBSON, M.J. The growth and development of simulated swards of perennial ryegrass. I. Leaf growth and dry weight change as related to the ceiling yield of a seedling sward. Annals of Botany, v.37, p.487-500, 1973.

SANTOS JR., J.D.; MONTEIRO, F.A.; LAVRES JR., J. Análise de crescimento do capim-marandu submetido a doses de nitrogênio. Revista Brasileira de Zootecnia, v.33, p.1985-1991, 2004.

SARMENTO, D.O.L. Produção, composição morfológica e valor nutritivo da forragem em pastos de Brachiaria brizantha (Hochst ex A. Rich) Stapf. cv Marandu submetidos a estratégias de pastejo rotativo por bovinos de corte. Piracicaba: USP/ESALQ, 2007. 144p. (Doutorado).
SOUZA JR., S.J. Estrutura do dossel, interceptação de luz e acúmulo de forragem em pastos de capim-marandu submetidos a estratégias de pastejo por bovinos de corte. Piracicaba: USP/ ESALQ, 2007. 122p. (Mestrado).

THORNTHWAITE, C.W.; MATHER, J.R. The water balance. Publications in Climatology, v.8, 104p. 1955.

TRINDADE, J.K. Modificações na estrutura do pasto e no comportamento ingestivo de bovinos durante o rebaixamento do capim-marandu submetido a estratégias de pastejo rotacionado. Piracicaba: USP/ESALQ, 2007. 162p. (Mestrado).

WATSON, D.J. The dependence of net assimilation rate on leaf area index. Annals of Botany, v.22, p.37-54, 1958.

WOLEDGE, J. The effects of shading and cutting treatments on the photosynthetic rate of ryegrass leaves. Annals of Botany, v.41, p.1279-1286, 1977.

WOLFINGER, R.D. Covariance structure selection in general mixed models. Communications in Statistics Simulation and Computation, v.22, p.1079-1106, 1993.

ZEFERINO, C.V. Morfogênese e dinâmica do acúmulo de forragem em pastos de capim-marandu [Brachiaria brizantha (Hochst. Ex A. Rich) cv. Marandu] submetidos a regimes de lotação intermitente por bovinos de corte. Piracicaba: USP/ESALQ, 2006. 193p. (Mestrado).

Received January 18, 2008

Accepted May 18, 2009 